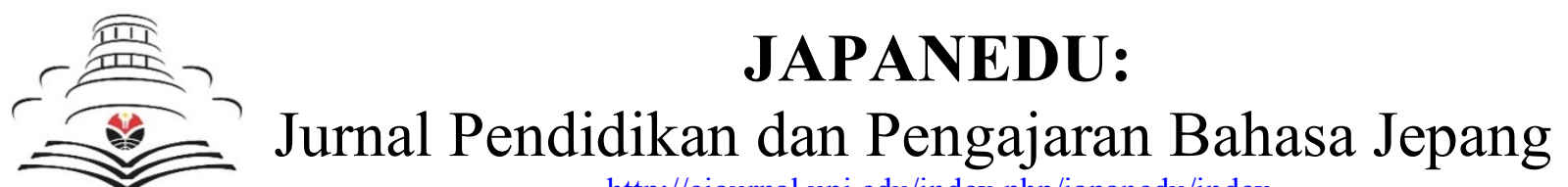

\title{
Using Vlog in Shokyu Kaiwa's Course to Improve Students' Speaking Ability
}

\author{
Melia Dewi Judiasri, Herniwati, Noviyanti Aneros \\ Departemen Pendidikan Bahasa Jepang, Universitas Pendidikan Indonesia, Bandung, Indonesia \\ meliadj@upi.edu
}

\begin{abstract}
The evaluation of Shokyu Kaiwa 1 and Shokyu Kaiwa 2 courses (basic speaking level 1 and 2) were mainly conducted using role play method, where students in pairs conducted a conversation about a theme within a predetermined duration of time. It is known that this kind of evaluation is considered to be less optimal to explore students' speaking abilities. Conversational material only revolves around simple everyday conversations that have been memorized before, and it is possible that they only memorize certain parts of the conversation. With this background, in this research, a method of evaluation that is approximated to be able to explore the ability to speak more optimally is done through vlog (video blogging) which has recently become a popular thing, especially among young people. This research is a descriptive study, with a sample of the Japanese language students major in the second semester of the year 2018 in Universitas Pendidikan Indonesia. The step taken in this study was stimulating students to prepare what must be discussed first, such as giving a variety of material relating to Japanese culture or Japanese habits. The results of this study showed that the students' speaking ability is increased, and students are conveying the conversation materials more freely. The sentence patterns used by students was not limited to the material that has been taught, but exceeded the sentence patterns given in the second semester. Further, students are able to develop the story materials given previously. Thus, it is known that the use of vlogs in evaluating the learning of the Shokyu Kaiwa course had a positive impact on improving the speaking skills of Japanese Language Education students.
\end{abstract}

K E Y W O R D S

Evaluation; Japanese; Speaking; Vlog

A R T I C L E I N F O

First received: 29 August $2019 \quad$ Final proof accepted: 15 December 2019

Available online: 29 December 2019

\section{PENDAHULUAN}

Pembelajaran Bahasa Jepang di Departemen Pendidikan Bahasa Jepang, Universitas Pendidikan Indonesia, diantaranya meliputi aspek-aspek yang berkenaan dengan empat keterampilan berbahasa yaitu menyimak, berbicara, membaca dan menulis. Penelitian ini membahas tentang hal-hal yang berkaitan dengan pembelajaran berbicara, mata kuliah tersebut diberikan di setiap semester yaitu shokyu kaiwa 1 (semester 1), shokyu kaiwa 2 (semester 2), chukyu kaiwa 1 (semester 3), chukyu kaiwa 2 (semester 4), chujokyu kaiwa 1 (semester 5) dan chujokyu kaiwa 2 (semester 6). 
Hingga saat ini dalam pembelajaran berbicara bahasa Jepang (kaiwa) lebih banyak menggunakan roleplay sebagai metode pengajarannya (Suryadi, 2014). Selain itu, dengar-ucap, ucap-ulang, tanyajawabdan roleplay merupakan kegiatan yang dilaksanakan untuk melatih keterampilan berbicara tingkat dasar (Judiasri, 2017). Hal ini sejalan dengan Iskandarwassid dan Sunendar (2015) yang menyatakan bahwa pembelajaran berbicara tingkat dasar seyogyanya bertujuan agar pembelajar dapat melafalkan bunyi-bunyi bahasa, dapat menyampaikan informasi, menyatakan setuju atau tidak setuju, menjelaskan identitas diri, menceritakan kembali hasil simakan, menyatakan rasa hormat dan bermain peran. Begitu pula pembelajaran mata kuliah shokyu kaiwa yang merupakan fokus dalam penelitian ini. Shokyu kaiwa mengutamakan latihan-latihan oral melalui roleplay, yang merupakan salah satu metode untuk pembelajaran berkomunikasi (Takami, 2004). Adapun tujuannya adalah memberikan kesempatan kepada pembelajar untuk berbicara dalam bahasa Jepang semaksimal mungkin. Meski memiliki kelebihan untuk mengutamakan latihan oral, roleplay juga memiliki kekurangan. Salah satunya adalah pembelajar hanya sekedar menghafal kalimat-kalimat yang telah disusun dan dipersiapkan sebelumnya.

Sementara itu, menilai kemampuan berbicara pembelajar bukanlah hal yang mudah untuk dilakukan. Lee (dalam Slamet, 2014) mengungkapkan bahwa alat penilaian (tes) harus dapat menilai kemampuan mengomunikasikan gagasan yang tentu saja mencakup kemampuan menggunakan kata, kalimat, dan wacana, yang sekaligus mencakup kemampuan kognitif dan psikomotorik. Kemampuan berbicara merupakan salah satu kemampuan berbahasa yang cukup kompleks karena tidak hanya mencakup intonasi saja, tetapi juga berbagai aspek seperti pelafalan, pengucapan, pemilihan kata, dan gerak gerik tubuh.

Sampai saat ini evaluasi dalam ujian akhir semester (UAS) mata kuliah shokyu kaiwa 1 maupun shokyu kaiwa 2 (berbicara tingkat dasar 1 dan 2) ini dilakukan dengan cara interviu dalam bahasa Jepang menyangkut hal-hal yang berkenaan dengan kegiatan sehari-hari atau pertanyaan-pertanyaan yang berkaitan dengan suatu tema yang telah ditentukan sebelumnya. Selain itu dilakukan pula evaluasi melalui roleplay (bermain peran), mahasiswa berpasangan melakukan percakapan tentang suatu tema dalam durasi waktu yang telah ditentukan. Menurut
Encalada (2018), melalui penggunaan roleplay sebagai alat evaluasi dalam pembelajaran berbicara, pengajar dapat menilai perkembangan kemampuan berbicara peserta didiknya. Hal ini akan terlihat dari bertambahnya penguasaan kosa kata, pemilihan tata bahasa yang tepat, pengucapan kosa kata dengan benar, dan lebih percaya diri (Encalada, 2018).

Berdasarkan pengkajian selama mengampu mata kuliah shokyu kaiwa (berbicara tingkat dasar) tersebut, diketahui bahwa evaluasi tersebut dirasa kurang maksimal untuk menggali kemampuan berbicara mahasiswa meskipun masih di tingkat dasar, karena materi percakapan yang digunakan pada umumnya hanya berkisar tentang percakapan sederhana sehari-hari yang telah dihafal sebelumnya, serta dimungkinkan hanya menghafal bagian-bagian percakapan tertentu saja. Suryadi (2014) mengatakan bahwa dengan hanya menghafal pola kalimat yang dipelajari, pada saat berkomunikasi pembelajar sering lupa dan sepertinya roleplay dalam kaiwa ini kurang berperan penting dalam berkomunikasi (Suryadi, 2014). Selain permasalahan tersebut di atas, diketahui pula kurangnya wawasan tentang 'kejepangan' seperti kebiasaan orang Jepang, budaya maupun karya sastra yang berdampak pada kurangnya ide/gagasan tentang apa yang harus diungkapkannya dalam percakapan. Dengan munculnya permasalahan tersebut di atas, maka penelitian ini sangat diperlukan untuk mengatasi masalah tersebut.

Upaya agar evaluasi dapat lebih menggali kemampuan berbicara mahasiswa, diperlukan evaluasi yang inovatif agar mahasiswa lebih dapat mengeksplorasi dan meningkatkan kemampuan berbicaranya dengan maksimal, yakni dengan cara (1) memberikan pengayaan materi literasi sebagai tema presentasi untuk memenuhi kebutuhan pengembangan wawasan terhadap pengetahuan 'kejepangan' dan untuk menumbuhkan kebiasaan membaca dan melatih untuk menerima informasi tentang apa yang dibacanya, (2) wawasan pengetahuan tentang 'kejepangan' berdasarkan literasi yang dipahaminya dipresentasikan dengan menggunakan bahasa Jepang dalam media vlog (videoblog) yang saat ini sedang sangat populer $\mathrm{di}$ berbagai kalangan.

Penggunaan media vlog (videoblog) menjadi perhatian dalam penelitian ini, karena seperti dikemukakan dalam Educause Learning Initiative (2005) bahwa Videoblog mampu memberikan stimulus untuk pembelajar, mengarahkan perhatian atau kegiatan pembelajaran sesuai 
dengan tujuan pembelajaran, fokus terhadap satu kemampuan yang diajarkan, dan penilaian hasil yang efektif. Mengacu pada hal tersebut di atas, diharapkan evaluasi pembelajaran mata kuliah shokyu kaiwa dengan memanfaatkan media vlog (videoblog) ini dapat lebih memacu kemampuan mahasiswa dalam berbicara. Adapun pemanfaatan media vlog (videoblog) tersebut dikemukakan oleh Baran (2007) diantaranya adalah untuk pemenuhan kebutuhan belajar karena videoblog dapat memperlihatkan situasi objektif dalam kehidupan bermasyarakat; alat untuk refleksi pembelajaran sehingga mampu memaparkan apa yang mereka ketahui, pelajari, dan apa yang akan mereka terapkan dalam kehidupan nyata; alat untuk memahami sebuah materi, dan melalui vlog dapat menceritakan pengalaman belajarnya ke dalam bentuk cerita digital. Hal ini didukung oleh Priana (2017) dalam hasil penelitiannya yang mengemukakan bahwa vlog (videoblog) merupakan perkembangan teknologi informasi yang dapat dijadikan sebagai media pembelajaran yang menyenangkan. Dijelaskan pula bahwa dampak perkembangan teknologi yang berimbas pada proses pembelajaran selalu relevan dengan perkembangan yang ada. Selain itu inovasi dan kreatifitas dapat dilakukan dengan penggunaan teknologi informasi sebagai media pembelajaran, dan media pembelajaran yang terintegrasi dalam teknologi informasi dapat menjadi daya tarik dan memberikan gairah belajar. Berkaitan dengan media vlog (videoblog) dalam pembelajaran berbicara dikemukakan oleh Lestari (2019) dalam hasil penelitiannya yang mengemukakan bahwa perspektif siswa terhadap penggunaan video blog melalui berbagai macam strategi sangat baik untuk meningkatkan kemampuan berbicara dalam bahasa Inggris. Akan tetapi pada penelitian tersebut tidak menjabarkan media vlog sebagai alat evaluasi untuk menggali kemampuan berbicara mahasiswa yang lebih maksimal. Berdasarkan pertimbangan atas hal-hal tersebut, maka penggunaan media vlog dalam evaluasi mata kuliah shokyu kaiwa ditenggarai dapat mengatasi permasalahan yang telah dikemukakan di atas.

\section{METODE PENELITIAN}

Penelitian ini dilaksanakan di Departemen Pendidikan Bahasa Jepang FPBS Universitas Pendidikan Indonesia. Subjek penelitian ini adalah mahasiswa Departemen Pendidikan Bahasa
Jepang FPBS UPI dengan menggunakan metode purposive sampling yakni memilih mahasiswa semester II yang mengikuti mata kuliah shokyu kaiwa II tahun 2018/2019 sebanyak 28 orang. Penelitian ini menggunakan metode deskriptif yang mendeskripsikan hasil evaluasi pembelajaran berbicara melalui penggunaan $v$ log, dengan teknik pengumpulan data berupa angket yang dilakukan guna mendapatkan data tentang respon dan pendapat mahasiswa berkaitan dengan penggunaan vlog dalam evaluasi mata kuliah berbicara ini, serta data tentang penilaian terhadap kemampuan menyampaikan isi wacana literasi dalam $v \log$ yang dibuat oleh responden.

Instrumen materi pembelajaran yang digunakan mengacu pada buku「たのしい 読み もの $55 」$ (Tanoshii Yomimono 55) Kazuko Shimada et.al. (2013), digunakan sebagai stimulan pengayaan literasi yang harus dibaca, dipahami dan diungkapkan dalam $v$ log sebagai berikut.

1) 日本の名物 (Nihon no Meibutsu)

Pemilihan wacana ini dimaksudkan agar pembelajar bahasa Jepang mengetahui 'sesuatu' yang terkenal di Jepang, Diantaranya memperkenalkan minuman sake Jepang yang terkenal dari Niigata, 'bi-doro' seruling gelas dari Nagasaki, apel yang sangat terkenal enak dan manis dari Aomori, dan sanuki udon yang enak dari Kagawa.

2) てるてる坊主 (Teru teru Bozu)

Wacana yang merupakan kebiasaan anakanak Jepang saat mengharapkan hujan tidak turun, dengan menggantungkan 'orangorangan'yang terbuat dari kertas tissue.

3) 八チ公 (Hachiko)

Wacana ini menceritakan tentang seekor anjing setia bernama 'hachi' yang dijadikan sebuah patung yang terletak di depan stasiun Shibuya.

4) お土産の始まり (Omiyage no Hajimari)

Wacana ini menerangkan tentang asal muasal kebiasaan membawa oleh-oleh ketika bepergian ke tempat yang jauh.

5) 旭山動物園(Asahiyama Doubutsuen)

Wacana ini menceritakan tentang keberadaan dan kondisi kebun binatang di Hokkaido yang terkenal.

6）お見舞い(Omimai) 
Wacana ini sangat menarik dan harus diketahui oleh orang-orang yang berhubungan dengan orang Jepang, yakni aturan atau kebiasaan membawa bunga yang seperti apa yang layak diberikan ketika menjenguk orang yang sedang sakit.

7) ご当地ラーメン(Gotouji Ra-men)

Ramen (makanan yang unsur utamanya adalah mie) sangat disukai, dalam wacana ini diperkenalkan berbagai macam dan jenis ramen yang terkenal di Jepang seperti Sano ramen, Sapporo ramen, Hakata ramen dan Tokyo ramen.

8) 祝日ともち(Shukujitsu to Mochi)

Mochi merupakan salah satu makanan khas Jepang yang terkenal. Dalam wacana ini dijelaskan tentang bentuk mochi, dan peruntukan jenis mochi tersebut.

9) かちかち山(Kachikachi Yama)

Wacana ini merupakan cerita anak-anak yang mengisahkan tentang perbuatan baik dan buruk.

10) 竹取物語(Taketori Monogatari) dan 鶴の恩返 L (Tsuru no Ongaeshi)

Wacana ini merupakan cerita klasik Jepang yang sangat terkenal.

11) 日本人の名字 (Nihonjin no Myouji)

Wacana ini berkaitan dengan penggunaan nama-nama dan maknanya bagi orang Jepang.

12) 部活！部活！部活！(Bukatsu! Bukatsu! Bukatsu!)

Wacana ini memperkenalkan kegiatan ekstra kurikuler yang dilakukan oleh para siswa di Jepang.

13) 和室の工夫(Washitsu no Kufuu)

Wacana ini memperkenalkan tipe tempat tinggal/rumah tradisional orang Jepang yang menjelaskan tentang unsur-unsur bahan bangunan dan pernak-perniknya.

14) お弁当(Obentou)

Wacana ini memperkenalkan tentang berbagai hal yang berkaitan dengan bento (makanan bekal untuk makan siang) yang biasa dibawa oleh para siswa ketika berangkat sekolah atau oleh para pegawai untuk makan siang.

Dalam pelaksanaan evaluasi dilakukan dengan melalui tahapan sebagai berikut:
1) Mahasiswa dibebaskan untuk memilih wacana literasi yang diminatinya merujuk pada materi buku「たのしい 読みもの 55 」 (Tanoshii Yomimono 55) Kazuko Shimada et.al. (2013).

2) Mahasiswa membaca dengan seksama dan memahami isi wacana tersebut.

3) Mahasiswa merencanakan dan mempersiapkan narasi maupun berbagai kreatifitas yang akan ditayangkan dalam $v$ log.

4) Sebagai evaluasi tahap akhir mahasiswa mempresentasikandan menayangkan $v \log$ yang dibuatnya dengan menggunakan bahasa Jepang.

Adapun instrumen pengumpulan data berupa angket meliputi pertanyaan-pertanyaan seperti pada Tabel 1 berikut.

Tabel 1: Kisi-kisi angket

\begin{tabular}{|c|l|c|}
\hline No. & \multicolumn{1}{|c|}{ Indikator Pertanyaan } & $\begin{array}{c}\text { Jumlah } \\
\text { pertanyaan }\end{array}$ \\
\hline 1. & $\begin{array}{l}\text { Untuk mengetahui } \\
\text { tanggapan mahasiswa } \\
\text { tentang manfaat pengayaan } \\
\text { literasi dalam pembelajaran } \\
\text { berbicara. }\end{array}$ & 2 \\
\hline 2. & $\begin{array}{l}\text { Untuk mengetahui } \\
\text { tanggapan mahasiswa } \\
\text { tentang penyusunan naskah } \\
\text { untuk vlog. }\end{array}$ & 2 \\
\hline 3. & $\begin{array}{l}\text { Untuk mengetahui } \\
\text { tanggapan mahasiswa } \\
\text { tentangide dan kreatifitas } \\
\text { dalam pembuatan } \text { vlog. }\end{array}$ & 2 \\
\hline 4. & $\begin{array}{l}\text { Untuk mengetahui } \\
\text { tanggapan/respon } \\
\text { mahasiswa dalam } \\
\text { pembuatan } \text { vlog secara } \\
\text { keseluruhan. }\end{array}$ & 1 \\
\hline
\end{tabular}

Sedangkan penilaian terhadap kemampuan berbicara dipadukan dengan penampilan dalam $v \log$, menggunakan penilaian dengan rubrikasi yang meliputi hal-hal sperti pada Tabel 2 . 
Tabel 2: Penilaian keterampilan berbicara

\begin{tabular}{|c|l|c|c|c|c|c|}
\hline No. & $\begin{array}{l}\text { Indikator } \\
\text { Kemampuan }\end{array}$ & $\begin{array}{c}\text { K } \\
\mathbf{1}\end{array}$ & $\begin{array}{c}\text { CB } \\
\mathbf{2}\end{array}$ & $\begin{array}{c}\text { B } \\
\mathbf{3}\end{array}$ & $\begin{array}{c}\text { SB } \\
\mathbf{4}\end{array}$ & $\begin{array}{c}\text { Jumlah } \\
\text { skor }\end{array}$ \\
\hline 1. & $\begin{array}{l}\text { Penggunaan } \\
\text { kosakata }\end{array}$ & & & & & \\
\hline 2. & $\begin{array}{l}\text { Penggunaan } \\
\text { tatabahasa } \\
\text { yang tepat }\end{array}$ & & & & & \\
\hline 3. & $\begin{array}{l}\text { Kelancaran } \\
\text { dan } \\
\text { kefasihan } \\
\text { berbahasa } \\
\text { Jepang }\end{array}$ & & & & & \\
\hline 4. & $\begin{array}{l}\text { Kreatifitas } \\
\text { penampilan } \\
\text { dalam vlog }\end{array}$ & & & & & \\
\hline
\end{tabular}

Keterangan:

$\mathrm{K}$ : kurang

CB: cukup baik

$\mathrm{B}$ : baik

SB : sangat baik

\section{HASIL DAN PEMBAHASAN}

Berdasarkan hasil dari pelaksaan penelitian ini diperoleh data sebagai berikut: 日本の名物/Nihon no Meibutsu (3 orang), てるてる坊主/Teru-teru Bouzu (3 orang), 八于公/Hachikou (3 orang), お 土産の始まり/Omiyage no Hajimari (1 orang), 旭 山動物園/Asahiyama Doubutsuen (2 orang), お見 舞い/Omimai (1 orang), ご当地ラーメン /Gotouchi no Ramen (3 orang), 祝日ともち /Shukujitsu Tomodachi (2 orang), かちかち山 /Kachikachi Yama (1 orang), 竹取物語/Taketori Monogatari dan 鶴の恩返し/Tsuru no Ongaeshi (2 orang), 日本人の名字/Nihonjin no Myouji (3 orang), 部活！部活！部活！/Bukatsu! Bukatsu! Bukatsu! (2 orang), 和室の工夫/Washitsu no Kuufu (1 orang) dan お弁当/Obentou (1 orang). Dengan demikian diketahui bahwa pembahasan melalui vlog ini meliputi:

1) Informasi yang berkaitan dengan pengetahuan umum yang perlu diketahui tentang Jepang yakni 日本の名物 (nihon no meibutsu), 旭山動 物園 (asahiyama doubutsuen), 日本人の名字 (nihonjin no myouji), 和室の工夫 (washitsu no kufuu).
2) Informasi yang berkaitan dengan kebiasaan, yakni てるてる坊主 (teruteru bouzu), お土産の 始まり(omiyage no hajimari), お見舞い(omimai).

3) Informasi yang berkaitan dengan makanan yakni ご当地ラーメン (gotouchi ra-men), 祝日 ともち (shukujitsu to mochi), お弁当 (obentou).

4) Informasi yang berkaitan dengan kegiatan ekstra kurikuler para siswa di sekolah-sekolah Jepang, yakni 部活! 部活！部活！(bukatsu! bukatsu! bukatsu!)

5) Informasi berkaitan dengan budaya berupa cerita klasik Jepang yakni 竹取物語(taketori monogatari) dan 鶴の恩返し (tsuru no ongaeshi).

6) Informasi yang berkaitan dengan cerita anak tentang perilaku baik dan buruk yakni かちか ち山 (kachi kachi yama).

7) Informasi yang berkaitan dengan salah satu tempat di Jepang yang terkenal yakni 八チ公 (hachikou)

Berikut pemaparan hasil penayangan $v \log$ yang dibuat oleh responden tersebut.

1) 日本の名物 (Nihon no Meibutsu)

3 orang responden yang memilih materi literasi ini menjelaskan tentang isi materi wacana serta menayangkan gambar yang disesuaikan dengan materi wacana tersebut yakni gambar sake Jepang 日本酒 yang berasal dari Niigata, ビードロ (seruling gelas) dari Nagasaki, apel yang enak dan manis dari Aomori, serta 讃岐うどん udon yang enak dari Kagawa dimana orang-orang Kagawa sering makan udon tersebut sepanjang tahun. Selain memaparkan isi wacana menggunakanbahasa Jepang dengan memperlihatkan gambar, kreatifitas mahasiswa ditunjukkan pula dengan memperlihatkan, peta dan beragam jenis gambar terkait serta membandingkannya dengan benda dan makanan sejenis yang ada di Indonesia.

2) てるてる坊主 (Teru teru Bozu)

3 orang responden memilih materi ini yang merupakan kebiasaan anak-anak Jepang saat mengharapkan hujan tidak turun, karena akan melaksanakan suatu kegiatan. Oleh sebab itu sehari sebelumnya mereka menggantungkan 'orang-orangan' yang terbuat dari kertas tissue. Kreatifitas yang ditunjukkan dalam tayangan vlog nya selain dengan memperlihatkan 
gambar, juga menayangkan video serta menyanyikan lagu tentang てるてる坊主 tersebut dan mengajarkan cara membuat 'orang-orangan' dari kertas tissue.

3) 八千公 (Hachiko)

Terdapat 3 orang responden yang memilih materi ini, yang menceritakan tentang seekor anjing setia bernama 'hachi' yang dijadikan sebuah patung yang terletak di depan stasiun Shibuya. Dalam penayangannya responden memperlihatkan gambar, foto, video maupun artikel yang berkenaan dengan materi tersebut.

4) お土産の始まり(Omiyage no Hajimari)

Terdapat seorang responden yang memilih materi ini yang menerangkan tentang asal muasal kebiasaan membawa oleh-oleh ketika bepergian ke tempat yang jauh. Responden ini selain menceritakan tentang materi, juga memberikan contoh gambar beragam oleh-oleh dari berbagai daerah di Jepang yang terkenal.

5) 旭山動物園 (Asahiyama Doubutsuen)

2 orang responden memilih materi ini tentang keberadaan dan kondisi kebun binatang di Hokkaido yang terkenal, harga tiket masuk serta video 'pinguin' yang ada di kebun binatang tersebut.

6) お見舞い(Omimai)

Seorang responden memilih materi ini yang berisi tentang aturan atau kebiasaan membawa bunga yang seperti apa yang layak diberikan ketika menjenguk orang yang sedang sakit. Responden memperlihatkan gambar dan nama bunga apa saja yang boleh dan tidak boleh diberikan ketika menjenguk orang yang sakit beserta alasannya.

7) ご当地ラーメン(Gotouji Ra-men)

3 orang responden memaparkan tentang sejarah 'ramen', sejenis makanan yang unsur utamanya adalah mie, serta menayangkan beragam jenis ramen yang terkenal di Jepang seperti 佐野ラーメン dari Tochigi, 博多ラー メン dari Fukuoka, 札幌ラーメン dariHokkaido, 東京ラーメンショーdari Tokyo, serta toko ramen terkenal lainnya.

8) 祝日ともち(Shukujitsu to Mochi)

2 orang respondenmemilih materi ini, memaparkan tentang mochi yang merupakan salah satu makanan khas Jepang yang terkenal. Dalam wacana ini dijelaskan tentang bentuk mochi, dan peruntukan jenis mochi tersebut. Selain itu dikemukakan pula tentang sejarah mochi, rasa, serta perbandingannya dengan aneka mochi yang terdapat di Indonesia. Kreatifitas responden ini dilengkapi pula dengan penayangan power point dan video.

9) かちかち山 (Kachikachi Yama)

Seorang responden menceritakan cerita anak-anak tentangperbuatan baik dan buruk yang disertai dengan gambar-gambar yang berkaitan dengan cerita tersebut.

10)竹取物語 (Taketori Monogatari) dan 鶴の恩返し (Tsuru no Ongaeshi)

Seorang responden menceritakan wacana ini yang merupakan cerita klasik Jepang yang sangat terkenal. Dalam penayangan vlognya, responden bercerita mengikuti alur gambar komik.

11) 日本人の名字 (Nihonjin no Myouji)

3 orang responden memaparkan tentang sejarah, makna serta penggunaan nama keluarga bagi orang Jepang. Responden juga menayangkan nama-nama keluarga yang menduduki 10 nama yang paling banyak digunakan di Jepang, jumlah nama keluarga yang digunakan, serta nama keluarga yang paling pendek dan paling panjang.

12)部活！部活！部活！(Bukatsu! Bukatsu! Bukatsu!)

2 orang responden memperkenalkan kegiatan ekstra kurikuler yang dilakukan oleh para siswa di Jepang. Dalam vlog ditayangkan gambar tentang beragam ekstra kurikuler baik berupa kegiatan olah raga maupun seni yang ditekuni para siswa di Jepang, selain itu ditayangkan pula video yang berkaitan dengan materi.

13)和室の工夫(Washitsu no Kufuu)

Seorang responden memaparkantipe tempat tinggal/rumah tradisional orang Jepang yang menjelaskan tentang unsur-unsur bahan bangunan dan pernak-perniknya. Dalam penayangan vlog disertai dengan gambar.

14)お弁当(Obentou)

Seorang responden memaparkan tentang berbagai hal yang berkaitan dengan bento (makanan bekal untuk makan siang) yang biasa dibawa oleh para siswa ketika berangkat sekolah atau oleh para pegawai untuk makan siang ini disertai dengan gambar jenis dan 
ragam bento yang sangat menarik dalam visualisasinya.

Pemaparan penilaian terhadap kemampuan berbicara yang dipadukan dengan penampilan dalam $v \log$ dideskripsikan sebagai berikut.

Tabel 3. Penilaian Kemampuan Berbicara dan Penampilan dalam $v \log$

\begin{tabular}{|c|c|c|}
\hline Responden & $\begin{array}{c}\text { Jumlah } \\
\text { Skor } \\
\text { Penilaian } \\
\text { Berbicara }\end{array}$ & $\begin{array}{c}\text { Penampilan dalam } \\
\text { Vlog }\end{array}$ \\
\hline $\mathrm{X} 1$ & 88 & $\begin{array}{l}\text { Penggunaan } \\
\text { tatabahasa dan } \\
\text { kosakata cukup baik } \\
\text { dan lancar. cukup } \\
\text { ekspresif dan } \\
\text { kreatifitasnya } \\
\text { ditunjukkan dengan } \\
\text { penayangan } \\
\text { perbandingan antara } \\
\text { mochi Jepang dengan } \\
\text { yang terdapat di } \\
\text { Indonesia. }\end{array}$ \\
\hline $\mathrm{X} 2$ & 90 & $\begin{array}{l}\text { Penggunaan } \\
\text { tatabahasa sangat baik } \\
\text { dan lancar. Kosakata } \\
\text { yang digunakan } \\
\text { banyak, ekspresif dan } \\
\text { kreatif. Penyampaian } \\
\text { alur cerita dan } \\
\text { penayangan video } \\
\text { tertata dengan baik. }\end{array}$ \\
\hline $\mathrm{X} 3$ & 93 & $\begin{array}{l}\text { Penggunaan } \\
\text { tatabahasa sangat baik } \\
\text { dan lancar. Kosakata } \\
\text { yang digunakan } \\
\text { banyak dan mampu } \\
\text { menggunakan } \\
\text { kosakata yang belum } \\
\text { diajarkan di semester } \\
\text { 2, ekspresif dan kreatif } \\
\text { dengan menayangkan } \\
\text { gambar dan foto yang } \\
\text { menarik. }\end{array}$ \\
\hline $\mathrm{X} 4$ & 88 & $\begin{array}{l}\text { Penggunaan } \\
\text { tatabahasa dan } \\
\text { kosakata cukup baik } \\
\text { dan lancar, ekspresif } \\
\text { dan kreatif dengan } \\
\text { menjelaskan sejarah } \\
\text { tentang materi yang } \\
\text { dibahas dan } \\
\text { menayangkan } \\
\text { beragam gambar yang } \\
\text { menarik. }\end{array}$ \\
\hline
\end{tabular}

\begin{tabular}{|c|c|c|}
\hline $\mathrm{X} 5$ & 80 & $\begin{array}{l}\text { Penggunaan } \\
\text { tatabahasa dan } \\
\text { kosakata cukup lancar } \\
\text { meskipun } \\
\text { menggunakan kalimat- } \\
\text { kalimat sederhana. } \\
\text { Kreatifitas } \\
\text { ditunjukkan dengan } \\
\text { penayangan cara } \\
\text { pembuatan teruteru } \\
\text { bouzu. }\end{array}$ \\
\hline X6 & 93 & $\begin{array}{l}\text { Penggunaan } \\
\text { tatabahasa sangat baik } \\
\text { dan lancar. Kosakata } \\
\text { yang digunakan } \\
\text { banyak dan mampu } \\
\text { menggunakan } \\
\text { kosakata serta } \\
\text { tatabahasa yang belum } \\
\text { diajarkan di semester } \\
\text { 2, sangat ekspresif dan } \\
\text { kreatif dengan } \\
\text { menayangkan video } \\
\text { dan foto yang } \\
\text { menarik. }\end{array}$ \\
\hline $\mathrm{X} 7$ & 88 & $\begin{array}{l}\text { Penggunaan } \\
\text { tatabahasa dan } \\
\text { kosakata cukup baik } \\
\text { dan } \\
\text { lancar.Penyampaian } \\
\text { cukup ekspresif dan } \\
\text { kreatif dengan } \\
\text { menyajikan data-data } \\
\text { terkait nama-nama } \\
\text { keluarga di Jepang. }\end{array}$ \\
\hline X8 & 91 & $\begin{array}{l}\text { Penggunaan } \\
\text { tatabahasa sangat baik } \\
\text { dan lancar. Kosakata } \\
\text { yang digunakan } \\
\text { banyak, dan sangat } \\
\text { ekspresif. Kreatifitas } \\
\text { ditunjukkan dengan } \\
\text { menambahkan } \\
\text { informasi terkait } \\
\text { tentang nama keluarga } \\
\text { di Jepang. }\end{array}$ \\
\hline X9 & 80 & $\begin{array}{l}\text { Penggunaan } \\
\text { tatabahasa dan } \\
\text { kosakata cukup lancar } \\
\text { meskipun } \\
\text { menggunakan kalimat- } \\
\text { kalimat sederhana. } \\
\text { Responden } \\
\text { menayangkan gambar } \\
\text { komik yang menarik. }\end{array}$ \\
\hline X10 & 80 & $\begin{array}{l}\text { Penggunaan } \\
\text { tatabahasa dan } \\
\text { kosakata cukup lancar } \\
\text { meskipun } \\
\text { menggunakan kalimat- }\end{array}$ \\
\hline
\end{tabular}




\begin{tabular}{|c|c|c|}
\hline & & $\begin{array}{l}\text { kalimat } \\
\text { sederhana.Kreatifitas } \\
\text { ditunjukkan } \\
\text { responden dengan } \\
\text { menginformasikan } \\
\text { tentang harga tiket, } \\
\text { letak tempat serta } \\
\text { video. }\end{array}$ \\
\hline $\mathrm{X} 11$ & 83 & $\begin{array}{l}\text { Penggunaan } \\
\text { tatabahasa dan } \\
\text { kosakata cukup lancar } \\
\text { meskipun } \\
\text { menggunakan kalimat- } \\
\text { kalimat sederhana. } \\
\text { Kreatifitas } \\
\text { ditunjukkan dengan } \\
\text { penayangan huruf- } \\
\text { huruf kanji yang } \\
\text { memberi penjelasan } \\
\text { tambahan terhadap } \\
\text { materi yang dibahas. }\end{array}$ \\
\hline $\mathrm{X} 12$ & 93 & $\begin{array}{l}\text { Penggunaan } \\
\text { tatabahasa sangat baik } \\
\text { dan lancar. Kosakata } \\
\text { yang digunakan } \\
\text { banyak dan mampu } \\
\text { menggunakan } \\
\text { kosakata yang belum } \\
\text { diajarkan di semester } \\
\text { 2, kreatifitas } \\
\text { ditunjukkan dengan } \\
\text { penayangan } \\
\text { gambar.Responden ini } \\
\text { kurang ekspresif } \\
\text { dalam } \\
\text { penyampaiannya dan } \\
\text { terkesan datar. }\end{array}$ \\
\hline $\mathrm{X} 13$ & 88 & $\begin{array}{l}\text { Penggunaan } \\
\text { tatabahasa dan } \\
\text { kosakata cukup baik } \\
\text { dan lancar, ekspresif } \\
\text { dan kreatif dengan } \\
\text { menambahkan } \\
\text { nyanyian terkait } \\
\text { materi yang dibahas. }\end{array}$ \\
\hline X14 & 88 & $\begin{array}{l}\text { Penggunaan } \\
\text { tatabahasa dan } \\
\text { kosakata cukup baik } \\
\text { dan lancar, ekspresif } \\
\text { dan kreatif dengan } \\
\text { menayangkan gambar- } \\
\text { gambar yang berkaitan } \\
\text { dengan tema. }\end{array}$ \\
\hline X15 & 90 & $\begin{array}{l}\text { Penggunaan } \\
\text { tatabahasa sangat baik } \\
\text { dan lancar. Kosakata } \\
\text { yang digunakan } \\
\text { banyak, ekspresif dan } \\
\text { kreatifitas ditunjukkan } \\
\text { dengan penjelasan }\end{array}$ \\
\hline
\end{tabular}

\begin{tabular}{|c|c|c|}
\hline & & $\begin{array}{l}\text { informasi tambahan } \\
\text { terkait tema yang } \\
\text { dibahas.. }\end{array}$ \\
\hline X16 & 88 & $\begin{array}{l}\text { Penggunaan } \\
\text { tatabahasa dan } \\
\text { kosakata cukup baik } \\
\text { dan lancar. Ekspresif } \\
\text { dan kreatifitas } \\
\text { ditunjukkan dengan } \\
\text { penayangan gambar } \\
\text { serta menambahkan } \\
\text { data artikel terkait } \\
\text { tema yang dibahas. }\end{array}$ \\
\hline X17 & 88 & $\begin{array}{l}\text { Penggunaan } \\
\text { tatabahasa dan } \\
\text { kosakata cukup baik } \\
\text { dan lancar, ekspresif } \\
\text { dan kreatif } \\
\text { menceritakan cerita } \\
\text { klasik sesuai dengan } \\
\text { alur gambar. }\end{array}$ \\
\hline X18 & 91 & $\begin{array}{l}\text { Penggunaan } \\
\text { tatabahasa sangat baik } \\
\text { dan lancar. Kosakata } \\
\text { yang digunakan } \\
\text { banyak, sangat } \\
\text { ekspresif dan kreatif, } \\
\text { karena memberikan } \\
\text { tambahan informasi } \\
\text { yang sangat berguna } \\
\text { dan perlu diketahui } \\
\text { dalam bersosialisasi } \\
\text { dengan orang Jepang. }\end{array}$ \\
\hline X19 & 88 & $\begin{array}{l}\text { Penggunaan } \\
\text { tatabahasa dan } \\
\text { kosakata cukup baik } \\
\text { dan lancar, ekspresif } \\
\text { dan kreatif dengan } \\
\text { membandingkan } \\
\text { keadaan yang ada di } \\
\text { negeri sendiri. }\end{array}$ \\
\hline X 20 & 88 & $\begin{array}{l}\text { Penggunaan } \\
\text { tatabahasa dan } \\
\text { kosakata cukup baik } \\
\text { dan lancar, ekspresif } \\
\text { dan kreatif. } \\
\text { Penayangan gambar } \\
\text { cukup menarik dan } \\
\text { informatif. }\end{array}$ \\
\hline $\mathrm{X} 21$ & 80 & $\begin{array}{l}\text { Penggunaan } \\
\text { tatabahasa dan } \\
\text { kosakata cukup lancar } \\
\text { meskipun } \\
\text { menggunakan kalimat- } \\
\text { kalimat sederhana. } \\
\text { Kreatifitas } \\
\text { ditunjukkan dengan } \\
\text { penayangan gambar } \\
\text { yang cukup menarik. }\end{array}$ \\
\hline
\end{tabular}




\begin{tabular}{|c|c|c|}
\hline $\mathrm{X} 22$ & 80 & $\begin{array}{l}\text { Penggunaan } \\
\text { tatabahasa dan } \\
\text { kosakata cukup lancar } \\
\text { meskipun } \\
\text { menggunakan kalimat- } \\
\text { kalimat sederhana. }\end{array}$ \\
\hline $\mathrm{X} 23$ & 80 & $\begin{array}{l}\text { Penggunaan } \\
\text { tatabahasa dan } \\
\text { kosakata cukup lancar } \\
\text { meskipun } \\
\text { menggunakan kalimat- } \\
\text { kalimat sederhana. } \\
\text { Cukup ekspresif } \\
\text { dengan penambahan } \\
\text { cara pembuatan dan } \\
\text { nyanyian. }\end{array}$ \\
\hline $\mathrm{X} 24$ & 76 & $\begin{array}{l}\text { Penggunaan } \\
\text { tatabahasa dan } \\
\text { kosakata sangat } \\
\text { sederhana serta } \\
\text { kurang lancar dalam } \\
\text { penyampaiannya. } \\
\text { Kreatifitas } \\
\text { ditunjukkan dengan } \\
\text { menambahkan } \\
\text { informasi terkait tema } \\
\text { yang dibahas. }\end{array}$ \\
\hline $\mathrm{X} 25$ & 78 & $\begin{array}{l}\text { Penggunaan } \\
\text { tatabahasa dan } \\
\text { kosakata sangat } \\
\text { sederhana serta } \\
\text { kurang lancar dalam } \\
\text { penyampaiannya. } \\
\text { Kreatifitas } \\
\text { ditunjukkan dengan } \\
\text { menambahkan } \\
\text { informasi sejarah } \\
\text { terkait tema yang } \\
\text { dibahas. }\end{array}$ \\
\hline X26 & 80 & $\begin{array}{l}\text { Penggunaan } \\
\text { tatabahasa dan } \\
\text { kosakata cukup lancar } \\
\text { meskipun } \\
\text { menggunakan kalimat- } \\
\text { kalimat sederhana. } \\
\text { Selain penjelasan } \\
\text { terkait tema, juga } \\
\text { menyertakan gambar } \\
\text { dan peta. }\end{array}$ \\
\hline $\mathrm{X} 27$ & 85 & $\begin{array}{l}\text { Penggunaan } \\
\text { tatabahasa dan } \\
\text { kosakata cukup lancar } \\
\text { meskipun } \\
\text { menggunakan kalimat- } \\
\text { kalimat sederhana. } \\
\text { Kreatifitas } \\
\text { ditunjukkan dengan } \\
\text { penayangan video } \\
\text { yang cukup menarik. }\end{array}$ \\
\hline
\end{tabular}

\begin{tabular}{|l|l|l|}
\hline & & $\begin{array}{l}\text { Penggunaan } \\
\text { tatabahasa dan } \\
\text { kosakata cukup baik } \\
\text { dan lancar, ekspresif } \\
\text { dan kreatif dengan } \\
\text { menayangkan peta } \\
\text { dan gambar yang } \\
\text { menarik. }\end{array}$ \\
\hline
\end{tabular}

Berdasarkan hasil angket diketahui bahwa pengayaan materi literasi 'kejepangan' dapat memperluas wawasan responden sehingga ide/gagasan menjadi lebih terbuka, karena literasi tersaji dalam kalimat-kalimat yang sederhana dan mudah dipahami serta isinya sangat menarik.

Gambar 1. Respon terhadap Materi Literasi

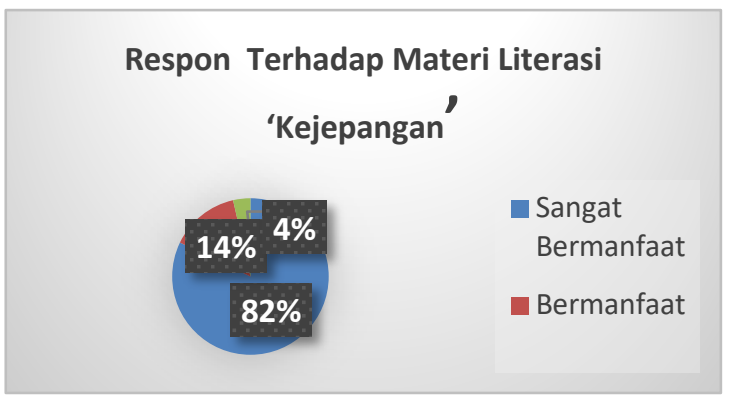

Seperti terlihat pada Gambar 1, berdasarkan hasil angket diketahui pula bahwa dengan membaca sebelum berbicara dapat lebih mudah dikemukakan dan dituangkan dalam bahasa Jepang pada saat menyusun naskah untuk vlog. Dalam pembuatan vlog dikemukakan bahwa sebagian besar responden merasa senang, namun adapula responden yang merasa 'terpaksa' saat pembuatan vlog karena tidak terlalu suka untuk tampil di depan kamera. Dari hasil angket ini diketahui pula terdapat hal-hal yang perlu dipertimbangkan dalam penugasan membuat $v \log$ ini, yakni berkaitan dengan piranti gawai (handphone) yang dimiliki responden.

Berdasarkan pengamatan dan penilaian diketahui beberapa hal sebagai berikut yang terbagi atas 3 kelompok.

Kelompok pertama yaitu kelompok dengan kemampuan tinggi. Sesuai dengan tingkatannya yakni tingkat 1 di semester 2, kelompok ini memiliki kemampuan berbicara cukup tinggi. Mereka dengan lancar dan fasih mampu menyampaikan materi menggunakan bahasa Jepang dengan frekwensi kesalahan tatabahasa minimal dan penggunaan kosakata yang lebih 
banyak meskipun belum diajarkan di semester 2 . Kelompok ini menyajikan vlog tidak hanya berbicara dengan tatap muka saja tetapi juga menyajikan gambar baik diam ataupun bergerak, menyertakan video, ataupun memvariasikan pembahasan materi dengan penggunaan huruf kanji. Kelebihan lainnya terdapat pula responden yang memadukan isi materi pembicaraan dengan membandingkan materi yang sama yang terdapat di Indonesia, sehingga kreatifitas kelompok ini sangat baik.

Kelompok kedua yaitu kelompok dengan kemampuan sedang. Kelompok ini tetap menunjukkan kreatifitas yang baik dalam penayangan $v \log$ seperti yang dilakukan pada kelompok dengan kemampuan tinggi, seperti memunculkan gambar maupun video yang berkaitan dengan materi. namun dalam kemampuan berbahasa Jepang masih terdapat kesalahan baik dalam penggunaan tatabahasa maupun penggunaan kosakata yang kurang tepat.

Kelompok terakhir yaitu kelompok dengan kemampuan rendah. Kelompok ini pada umumnya menggunakan kalimat dan ungkapan yang sederhana, dan cenderung membaca teks, namun demikian kelompok ini pun menyajikan penayangan yang menunjukkan eksistensinya masing-masing.

Berdasarkan hasil tersebut di atas, diketahui bahwa hal-hal positif muncul dari penggunaan $v \log$ ini, meskipun secara keseluruhan masih terdapat kemampuan yang bervariasi sehingga memunculkan pemilahan kemampuan dengan kualitas tinggi, sedang dan rendah. Hasil dari penelitian ini dimaksudkan untuk memaparkan bahwa sebagian besar mahasiswa mampu mengeksplorasi kemampuannya dalam menyampaikan materi percakapan, selain itu kemampuan berbicara mahasiswa lebih meningkat, pola-pola kalimat yang digunakan tidak terbatas pada materi yang telah diajarkan saja tapi sudah melampaui pola-pola kalimat yang diberikan pada semester 2 ini, selain itu mahasiswa mampu mengembangkan materi cerita yang diberikan sebelumnya dengan ide-ide yang patut diapresiasi. Sementara itu, mahasiswa yang masih belum dapat meningkatkan kemampuannya ditenggarai karena kurangnya latihan karena evaluasi seperti ini merupakan evaluasi baru dalam mata kuliah kaiwa tingkat dasar.

Sedangkan mengenai respon terhadap penggunaan vlog, seperti terlihat dari Gambar 2, responden pada umumnya menunjukkan hal yang positif, diketahui bahwa sebagian besar mahasiswa menikmati evaluasi yang dilakukan menggunakan vlog ini, mahasiswa merasa 'dibebaskan' untuk menyalurkan kreatifitasnya secara individu, berupaya keras untuk mewujudkan ide-idenya.

Gambar 2. Respon terhadap Ketertarikan pada Vlog

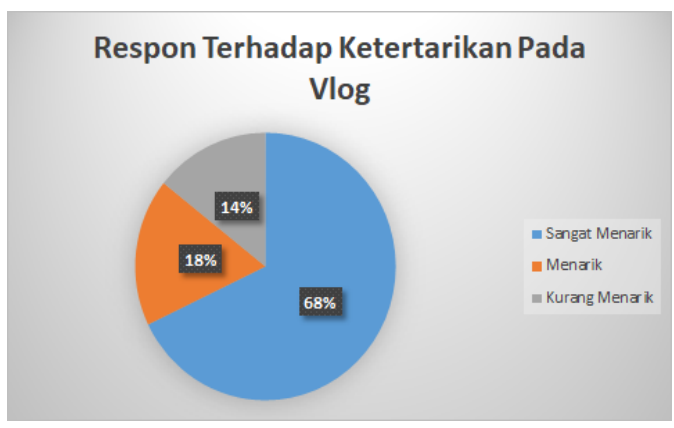

Namun terdapat pula hal-hal yang perlu dipertimbangkan dalam evaluasi menggunakan vlog ini yakni berkaitan dengan responden dalam kelompok berkemampuan rendah, yakni sebaiknya ada tuntunan mengenai apa yang harus dilakukan dalam penayangan vlog sehingga penayangan yang diperkirakan 'seperti membaca' dapat dihindari. Sehingga diharapkan hasilnya menjadi penayangan $v \log$ berbahasa Jepang yang kreatif dan dinamis.

\section{SIMPULAN}

Hasil dari penelitian ini diketahui bahwa hal-hal positif muncul dari penggunaan $v \log$ ini, diantaranya mahasiswa lebih mampu mengeksplorasi kemampuannya dalam menyampaikan materi percakapan. Literasi yang berkaitan dengan wawasan pengetahuan pun berdampak positif yang meliputi pengetahuan umum tentang Jepang, kebiasaan orang jepang dalam berkehidupan bermasyarakat, makananmakanan yang merupakan makanan tradisional dan terkenal di Jepang, jenis dan ragam kegiatan ekstra kurikuler siswa di Jepang, budaya klasik Jepang, cerita anak tentang perilaku baik dan buruk, serta asal usul suatu tempat yang terkenal di Jepang. selain itu kemampuan berbicara mahasiswa lebih meningkat, pola-pola kalimat yang digunakan tidak terbatas pada materi yang telah diajarkan saja tapi sudah melampaui polapola kalimat yang diberikan pada semester 2 ini, serta mahasiswa mampu mengembangkan materi cerita yang diberikan sebelumnya. Dengan demikian penggunaan vlog dalam evaluasi pembelajaran mata kuliah shokyu kaiwa ini dapat 
dijadikan alternatif dalam meningkatkan kemampuan berbicara mahasiswa Departemen Pendidikan Bahasa Jepang.

\section{REFERENSI}

Baran, E. (2007). The Promises of Videoblogging in Education. The Association for Educational Communications and Technology (AECT), International Convention, California.

EDUCAUSE Learning Initiative. (2005). Things You Should Know About Videoblogging. EDUCAUSE. Retrieved from http://www.educause.edu/ir/library/pdf/ELI7005 .pdf

Encalada, M. R. (2018). Role-plays as an Assessment Tool in English as a Foreign Language (EFL) Class, Beyond Paper-and-Pencil Tests: Good Assessment Practices for EFL Classes, ISBN: 978-9942-24-111-5.

Iskandarwassid \& Sunendar, D. (2015). Strategi Pembelajaran Bahasa. Bandung:Remaja Rosdakarya.

Judiasri, M. D. KOTO RENSHU DALAM PEMBELAJARAN KAIWA (BERBICARA) DI DEPARTEMEN PENDIDIKAN BAHASA JEPANG FPBS UPI. JAPANEDU: Jurnal Pendidikan dan Pengajaran Bahasa Jepang, 2(1), 29-39.

Lestari, N. (2019). Improving the Speaking Skill by Vlog (video blog) as Learning Media: The EFL Students Perspective, International Journal of Academic Research in Business \& Social Sciences, ISSN:22226990.

Slamet. (2014). Pembelajaran Keterampilan Berbahasa Indonesia. Yogyakarta: Graha Ilmu.

Suryadi, D. (2014). Pengajaran Debat dalam Mata Kuliah Chuukyu Kaiwa untuk Meningkatkan Kemampuan Berkomunikasi dalam bahasa Jepang, Jurnal Pendidikan Bahasa Jepang ASPBJI Korwil Jabar, 8 (2).

Takami. (2004). Shin Hajimete no Nihongo Kyojuho 2, Aruku. Tokyo.

Priana, R. Y. S. (2017). Pemanfaatan Vlog sebagai Media Pembelajaran Terintegrasi Teknologi Informasi, Prosiding Seminar Nasional Pendidikan FKIP UNTIRTA 2017, ISBN 978-602-19411-2-6. 